\title{
Türkiye İktisat Tarihinde Öznel Boyutları ile Müdahaleciliğin Gelişimi ve Kurumsallaşması: Etibank Örneği *
}

\section{The Development and Institutionalization of Interventionism with Subjective Facts in Turkish Economic History: Etibank Model}

\author{
Bengü Doğangün Yasa ${ }^{\text {a,** }}$ \\ ${ }^{a}$ Dr., Kocaeli Üniversitesi, İktisadi ve İdari Bilimler Fakültesi, İktisat Bölümü, 41380, Kocaeli/Türkiye.
} ORCID: 0000-0003-4883-9449

\section{MAKALE BILLGİSI}

\section{Makale Geçmişi:}

Başvuru tarihi: 18 Haziran 2018

Düzeltme tarihi: 30 Temmuz 2018

Kabul tarihi: 08 Ağustos 2018

\section{Anahtar Kelimeler:}

Devlet Müdahaleciliği

Devletçilik

Etibank

\section{A R T I C L E I N F O}

\section{Article history:}

Received June 18, 2018

Received in revised form July 30, 2018

Accepted August 08, 2018

\section{Keywords:}

State Interventionism

Statism

Etibank
ÖZ

Türkiye iktisat tarihinde Cumhuriyetin erken dönemlerinden itibaren devlet müdahaleciliği kurumsal bir çerçeve içerisinde oluşturulmaya çalışılmıștır. Bu çalışma müdahaleciliği ağır sanayi alanında temsil etmek üzere kurulan Etibank'ın 1935-1950 tarihleri arasındaki faaliyetlerini ve bu dönemde gerçekleştirilen yasal düzenlemeleri analiz ederek; Türkiye'de devlet müdahaleciliğinin kurumsal boyutlarını ortaya çıkarmayı amaçlamaktadır. Türkiye iktisat tarihinin belirli bir döneminde oluşturulmaya çalışılan ekonomi politiğin, kurumsal bir örnek üzerinden analizi, müdahaleciliğin niteliğinin tanımlanmasına katkı sağlayacaktır. Çalışmada Etibank'ın kuruluş yıllarını takiben faaliyetleri genel çerçevede incelenmiş; Türkiye'de devlet müdahaleciliğinin pragmatik nitelikler sergilediği gözlenmiştir.

\section{A B S T R AC T}

The state interventionism was tried to be arranged in an institutional framework in Turkish economic history from the early periods of the republic. This study aims to find out the corporate facts of the state interventionism in Turkey by analyzing activities of Etibank which was established for representing the interventionism in the heavy industry area between 1935-1950 and legal regulations were made in those years. Analyzing Turkish political economy in a particular time using an institution contributes to characterize interventionism. In this study Etibank's activities were observed and it was revealed that Turkish state interventionism had pragmatic features.

\section{Giriş}

Liberalizm ve müdahalecilik kavramları iktisat teorisi içerisinde gerçekleşen çalışmaların temelinde yer alır. Devlete ve devlet müdahaleciliğine yönelik farklı görüşler bu kavramlara ilişkin tartışmalar sonucu ortaya çıkmıştır. Devlet müdahalesinin sinırlarının çizilmesinde bu tartışmalar etkili olmuştur.

Geri kalmışlık sorunun aşılabilmesi dünyadaki pek çok ülke için önem taşımaktadır. Yoksulluk sorununun çözülebilmesi için yoğun çaba sarf edilmektedir. Gelişme sürecinde bulunan ülkelerin sahip oldukları temel hedef, yüksek büyüme oranları yakalayarak gelişmiş ülkeler ile aralarında oluşan açığı kapatabilmektir. Toplumların kalkınma düzeyi eğitim, sağlık, kültür gibi pek çok gerekliliği barındırsa da, ağırlıklı olarak sanayileşme olgusunu ifade etmektedir.

Cumhuriyetin kurulması ile birlikte Türkiye'de devlet müdahaleciliği kurumsal bir çerçeve içerisinde yapılandırılmaya çalışılmıştır. Ana hedefi sanayileşme olan bu kurumsal model gelişmekte olan diğer ülkelerle ortak pek çok hedef içerse de, öznel birtakım gereklilikleri de barındırmaktadır. Bu çalışmada süreç içerisinde kurulan

\footnotetext{
* Bu çalışma, 2017 yılında Kocaeli Üniversitesi Sosyal Bilimler Enstitüsü tarafından kabul edilen “Türkiye'de Planlama Döneminde Devlet Müdahaleciliğinin Imalat Sanayi Üzerindeki Etkileri: 1963-1989 Dönemi için Kliometrik Bir İnceleme” adlı Doktora tezinden türetilmiştir.

** Sorumlu yazar/Corresponding author.

e-posta: bengudogangun@gmail.com
} 
önemli bir kurum olarak Etibank örnek olarak incelenecek; müdahalecilik sürecindeki kurumsallaşma modeli içerdiği öznel unsurları çerçevesinde tanımlanmaya çalışılacaktır.

\section{Cumhuriyet \\ Döneminde \\ Devlet Müdahaleciliğinin Uygulanışı: Liberal Siyasa İçinde Müdahalecilik}

Cumhuriyet'in kurulması ile birlikte Türkiye'de devletçiliğe geçiş için elverişli bir ortam oluşmuştur. Osmanlı Devleti'nden miras alınan müdahaleci devlet anlayışının da etkisi ile devlet, ekonominin en önemli unsurlarından biri olarak tanımlanmıştır. Milli burjuvazinin oluşturularak ulusal bir ekonominin kurulması temel hedef haline gelmiştir. İlgili dönem liberal ekonominin kuralları ile uyum gösterse de, devletçilik politikasının temelleri 'Milli İktisat' politikası uygulamalarının başladığı bu dönemde atılmıștır (Ahmad, 1980: 332).

Cumhuriyet döneminde devlet merkezli ilk kurumsal model 1925 yılında kurulan Sanayi ve Maadin Bankası'dır. Sermaye eksikliği ve teknik yetersizliklerin sanayinin oluşumunda yetersiz kalması nedeniyle kurulan banka; bizzat veya iştirak yoluyla sanayi yatırımlarında bulunmak, bunları işletmek, Osmanlıdan devralınan ve ekonomik açıdan kötü durumdaki fabrikaları sslah etmek, maden yatırımları yaparak işletimlerini üstlenmek ve sanayi sektörüne kredi sağlamak gibi amaçlar taşımaktadır (TBMM Zabit Ceridesi, 1925).

1925 yllında kurulan Sanayi ve Maadin Bankası aslında 1930'lu yılların devletçiliğinin habercisi sayılabilir. Banka, kuruluş kanunuyla Osmanlı devletine ait dört sınai işletmeyi devralmıştır. Ancak bu bankanın kendisinin sınai tesis kurması amaçlanmamış ve devraldığı tesisleri de uygun şartlarla özel girişimcilere devretmesi dile getirilmiştir. Bankanın kuruluşunun asıl amacı ise özel sanayi ve maden işletmelerini kredi ve iştiraklerle desteklemesidir. $\mathrm{Bu}$ bankanın desteğiyle Kayseri- Bünyan İplik Fabrikası TAŞ, Isparta İplik Fabrikası TAŞ, Kütahya Çini İşleri TAŞ ve bunlar gibi birçok özel kuruluş devletin de ortak olmasıyla faaliyete geçmiştir (Kuyucuklu, 1986: 180).

Dönem içerisinde bir iktisadi danışmanlık görevi üstlenen "Âli İktisat Meclisi” 1927 yılında kurulmuştur. Meclis, Hükümet, Ticaret ve Sanayi Odaları ve diğer meslek gruplarından oluşmuştur. Amacı, araştırmalar yaparak, iktisadi gelişmeyi hızlandıracak kararlar alınmasına yardımcı olmak olarak belirlenmiştir. Dönemin iktisat politikalarıyla ilgili bilgi ve tartışma zeminini genişletmeye başlamıştır (Tezel, 2000: 230). 1929 y1lında Meclis'ten ödemeler dengesi açığının kapatılması için gerekli olanakları araştırması, sanayileşmenin hızlanmasını sağlayabilecek koşulları içeren bir iktisadi program hazırlamaları istenmiştir (Tekeli ve İlkin, 1977: 99).

Âli İktisat Meclisi iktisat politikalarının belirlenmesi konusunda yardımcı bir kuruluş olarak tasarlanmıştır. $\mathrm{Bu}$ kurumsal model aynı dönemde bazı Avrupa ülkelerinde de görülmektedir. Temel kurulma hedeflerinden biri, özel kesimin talep ve sorunlarının siyasi iktidara iletilmesinde rol alarak özel kesimin temsil edilmesine olanak sağlamaktır. Böylelikle farklı toplumsal kesimlerin çıkarlarının uzlaştırılmasının mümkün olacağı düşünülmüsşür (Tekeli ve İlkin, 1977: 60). Ali İktisat Meclisinin kurumsal yapısı ileri bir ekonomik planlama anlayışını barındırmaktadır (Aysan, 1980: 98).

Meclis tarafindan 1933 yılında hazırlanıp dönemde İktisat Bakanı olan Celal Bayar'a sunulan raporda, devlet teşebbüsü ile kurulacak sanayilerde, teşebbüsler kar etmeye başladığında, özel müteşebbislere devredilmeleri gerektiğinden bahsedilmektedir (Ali İktisat Meclisi, 1933: 12). Bu kararla birlikte devlet eliyle sanayileşmeye hız vermek adına kurulacak olan kamu iktisadi teşebbüslerinin ilk adımı atılmıştır.

Dönem içerisinde yaşanan 1929 Dünya bunalımı tüm dünyada olduğu gibi Türkiye'de de devlet müdahaleciliğini önemli ölçüde etkilemiştir. Bunalım iktisadi düşüncede yol açtı̆̆ dönüşümle birlikte iktisadi politikaların da dönüşümünde önemli bir role sahiptir. Bunalımı Türkiye ekonomisine taşıyan en önemli süreç tarımsal malların fiyatlarında ortaya çıkan keskin düşüş olmuştur. Tarımsal ürün fiyatları 1928-29'dan 1932-33'e kadar yaklaşık \% 60 oranında düşüş göstermiştir. Tarımsal ürün fiyatlarındaki düşüşle birlikte ülkenin dış ticaret hadlerinde $\% 25$, tarım sektörü iç ticaret hadlerinde $\% 31$ oranında düşüş yaşanmıştır (Pamuk, 2012: 173). Büyük ekonomik bunalım sonrasında iç ve dış pazarlara daha fazla yönelmiş olan Anadolu'nun tarım kesiminde başlayan ve bu bölgelerden kent ekonomilerine sıçrayan güçlükler, 1932 yılında devlet öncülüğ̈̈ndeki ithal ikameci sanayileşme stratejisinin benimsenmesinde önemli rol oynamıştır (Pamuk, 2012: 175).

1923-1932 yılları arasında uygulanan liberal iktisadi siyasa sonucunda tüketim malları sanayilerinde belirgin bir artış gözlense de, bu artış beklenen üretim artışının altında kalmıştır. Dönemde özel girişimci, kâr oranının daha yüksek olduğu ticari alanlara yönelmiştir. Devleti yönetenlerin özel girişimi başarısız bulması ve değişen konjonktürel koşullar devlet müdahaleciliğinin benimsenmesine yol açmıştır. Bu anlamda somut adımlar 1932 yılında atılmasına karşın liberal görüşler karşısında gelişen yeni siyasanın bu tarihten önce doğduğu söylenilebilir.

\section{Türkiye'de Devlet Müdahaleciliğinin Kurumsallaşma Süreci: 1933-1950 Dönemi}

Türkiye'de 1930'ların başlarında kamu kesimi tarafından iktisadi teşebbüsler kurulmaya başlanmıştır. 1929 Dünya Buhranı, iktisat politikalarının düzenlenmesini gerektiren önemli bir faktör olmuş, devletçilik uygulamalarının başlatılmasını zorunlu kılmıştır (Okyar, 1995: 191). Liberal iktisat politikalarına duyulan güven azalmış, devletin iktisadi meselelerle daha fazla iç içe olması ihtiyacı doğmuştur. Hükümet iktisadi ve sosyal uygulamalarını formüle ederken devletçiliğe çok daha fazla ağırlık vermiştir. Yalnızca Türkiye'de değil, pek çok ülkede hükümetler, ekonomiyi daha yakından yönlendirme eğilimine içerisine girmiştir (Çavdar, 1983: 1068).

Devletçilik sisteminin temel hedefi, ekonomik gelişme için, siyasi ve ekonomik bağımsızlığın devlet denetiminde sağlanması olmuştur. Bu sistemin kurulması için kamu teşebbüslerinin kurulması, sanayileşmenin sağlanması, sermaye ve emek faktörleri arasında denge kurulması, fiyat denetiminin sağlanması ve dış ticarette korumacı politikalar uygulanması öngörülmüştür (Herslag, 1995: 212). 
İktisadi yaşamda devletin yer alması bağlamında düşünsel anlamda bir takım yenilikler 1930'lu yıllardan itibaren görülmeye başlanmıştır. Devleti yönetenlerin iktisadi yaşam konusundaki düşünceleri, tecrübeleri doğrultusunda olgunlaşmış, özel girişimin başarısızlığı da bu duruma eklenince, geri kalmış bir ekonomik yapıdan kurtulmak için ekonomik yaşama doğrudan devlet müdahalesinin gerekli olduğuna karar verilmiştir (Altıntaş, 1978: 99-100).

Türkiye'de devletçilik ilkesi hiçbir zaman bir doktrine ait olmamıştır. Devletçilik sosyalizmin tarafindan desteklenen fikirlerden beslenmemiş, tamamen tarihsel nedenlerden kaynaklanmıştır (Laufenburger, 1941: 239). Özel girişim milli ekonomi içerisinden hiçbir zaman dışlanmamış, aksine milli ekonomi içerisinde varlığının sağlanması ve gelişiminin sürdürülmesi için her türlü olanağı bulabilmiştir. Devletçilik iktisadi gelişmenin sağlanması ve sürdürülmesinde etkin bir araç olarak kullanılmıştır. Ülkenin ihtiyacı olan sınai teşebbüslerin kurulması ve piyasa ekonomisi koşullarının sağlanması meselelerinin, devlet desteği olmaksızın sürdürülemeyeceği inancından hareket edilmiştir (Alp, 1936: 203).

Türk devletçiliği, özel teşebbüslerin devlet tarafindan işletilmesi anlamına gelmemektedir. İktisadi anlamda kurtuluşu sağlayabilmek için devletin yönelmesi gereken politika ve uygulamaları içermektedir (Derin, 1940: 4). İsmet İnönü devletçilik politikasının öncelikle bir müdafaa aracı olduğunu belirtmekte, bu sistemin ülkenin gelişmesi için zorunlu bir seçenek olduğunu vurgulamaktadır (İnönü, 1933: 4).

Türk hükümetinin temel hedefi haline gelmiş olan iktisadi bağımsızlık ve hızlı kalkınma sorunsalı 1931 yılı sonlarına doğru biraz daha belirginleşmiş, yöneticilerin devletçilik politikasını tercih etme eğiliminin kuvvetlenmesine yol açmıştır. Cumhuriyet sonrası uygulanan liberal politikalar, iktisadi bağımsızlık ve hızlı kalkınma hedeflerinin gerçekleşmesi sürecinin, sadece özel girişimcinin korunduğu ve teşvik edildiği bir iktisadi politika anlayışı ile mümkün olamayacağını gözler önüne sermiştir. Yöneticiler ülkenin içerisinde bulunduğu bu durum nedeniyle, iktisadi anlamda köklü önlemler alma ihtiyacı hissetmiştir. Tüm bu koşullar sebebiyle devlet ekonominin her sahasına çeşitli müdahalelerde bulunmaya başlamıştır. Kullanılan müdahale araçları; farklı sektörlerde devlet teşebbüsleri kurulması, sabit sermaye yatırımları yapılması, piyasanın denetlenmesi ve kontrol altında tutulması gibi pek çok alanı kapsamıştır (Çavdar, 2003: 246).

Mustafa Kemal Atatürk, çıktığı yurt gezilerinde hükümete duyulan hoşnutsuzluğun temel nedeninin iktisadi sorunlardan kaynaklandığını tespit etmiş, iktisadi kalkınmanın hızlı bir biçimde sağlanması zorunluluğunu bir devrim prensibi olarak benimsemiştir. $\mathrm{Bu}$ zorunluluğun temel çözüm yolu olan hızlı sanayileşme sorunsalının özel kesim aracılığı ile gerçekleştirilemeyeceği açık biçimde anlaşılmıştır (Boratav, 1974: 136-137). Bu durum devletin iktisadi sahada faaliyette bulunması zorunluluğunu doğurmuştur. Cumhuriyet Halk Fırkası'nın programına, 1937 y1lında "Devletçilik İlkesi”" eklenerek, devlet eliyle sanayileşmenin ilk adımı atılmıştır (Tezel, 2000: 6-7).

Devletçi politikaların uygulanması, Merkez Bankasının kurulması, bankacılık sektörünün gelişmesi, sanayi politikalarının plan temeline oturtulması, yeni bir döviz kuru politikası, yerli malının kullanılmasının teşvik edilmesi, demiryollarının inşa edilmesi ve işletim hakkının devlet eliyle kullanılması gibi pek çok yeniliğe sahne olmuştur. Ancak bu dönemde görülen devletçilik uygulamalarının en önemli özelliği, özel girişim ve sermayenin teşvik edilmesi olmuştur.

1930-1939 yılları uygulanan iktisat politikaları açısından korumacılık ve devletçiliğin hâkim olduğu dönemler olarak nitelenebilir. İktisat politikaları ve siyasi rejim önemli bir dönüşümden geçmiştir. Ticaret burjuvazisinin karşılaştığı güçlükler ve kriz, yeni iktisadi politika seçeneklerinin hazırlanmasına sebep olmuştur. Türkiye iktisat tarihinde devletçilik politikalarına zemin hazırlayan temel etken, bu iki gelişmenin birbiriyle kesişmesi olmuştur. Başlangıçta krizle mücadele amacı için formüle edilen tedbirler giderek yeni bir devlet biçimini doğurmuştur (Keyder, 1993: 135).

Türkiye'de bu yıllarda devlet müdahalesinin somutlaşması en belirgin biçimde millileştirme politikaları üzerinden gerçekleşmiştir. Özellikle sanayinin kurulması ve geliştirilmesinde en çok başvurulan müdahale biçimi millileştirme politikaları olmuştur (Laufenburger, 1941: 238-239).

$\mathrm{Bu}$ dönemde uygulanan sınai politikalar ve millileştirme hareketleri ticari sermaye grubuna zarar vermiş, imalat sanayi ise büyük yarar sağlamıştır. Sınai faaliyetlerin korunması ve teşvik edilmesi, imalat sanayinin GSMH içindeki payının 1925-1929 yılları arasındaki \% 10,5'lik değerinden, 1935 yılında \% 16,6 değerine çıkmasında önemli rol oynamıştır (Keyder, 1993: 143). 1939 yılına gelindiğinde firma başına gayri safi üretim düzeyi 1932 yılında ulaşılan değerin 2,4 katına yükselmiştir. Aynı yıl devlet teşviklerinden yararlanan firmalar, sanayi kesiminde çalışan tüm işçilerin \% 25 kadarını istihdam etmişlerdir (Kazgan, 1978: 263).

Devletçilik sisteminin temel amacı kapitalizmi geliştirmek olmuştur. Bu hedef doğrultusunda içselleştirilen politikalar istenilen sonuca ulaşılmasını sağlamıştır. Devletçilik fiziksel açıdan önemli tesisler ortaya çıkarmış, ayrıca özel kesime gizli fonlar akıtmak suretiyle, kapitalizmin gelişiminde bir ön aşama olmuştur. Devletçilik eylemi, Türkiye'de sanayileşmenin kurumsallaşması bakımından en kritik uygulama olmuştur (Gevgilili, 1987: 48-49). Devlet müdahaleciliğinin somutlaşması çeşitli kurumların ortaya çıkışı ile gerçekleşmiştir. Bu bağlamda Türkiye'de devlet müdahaleciliği kurumsallaşmaya başlamıştır.

Meclise 1932 yılında sunulan kanun tasarısında, 1925 y1lından beri faaliyetlerini sürdüren Sanayi ve Maadin Bankası'nın görevlerini yapmada yetersiz kaldığına dikkat çekilmiştir. Belirli mali görevler yüklenen kurum, yönetimini devraldığı kurumların mali durumlarını düzeltme faaliyetine eğilmiş, kredi verme görevini tam olarak yerine getirememiştir (TBMM Zabıt Ceridesi, 1932a). Bu durum yönetim ve kredi verme faaliyetlerinin iki farklı kurum tarafından üstlenilmesinin daha verimli olacağ düşüncesinin ortaya çıkmasına sebep olmuştur. Devlet Sanayi Ofisi'nin kurulması ve Sanayi ve Maadin Bankası'nın yönetim faaliyetlerini devralması 3 Temmuz 1932'de yapılan oturumda karara bağlanmıştır. Kabul edilen 2058 sayılı kanunda, devlet teşebbüsü olarak ya da devlet sermayesi ile kurulan sanayi kurumlarının yönetiminin Ofis'e devredildiği yer almıştır. İktisat Vekâleti'nin denetimi altında faaliyet 
gösterecek olan Ofis'e; fabrikaların faaliyetlerinin İktisat Vekâleti'nce belirlenecek hususlar dâhilinde denetlenmesi ve denetim faaliyetleri sonucu gerekli raporların hazırlanması, temininde sıkıntı yaşanan hammadde ve ara mallarının üretimini artırıcı tedbirler alınması, Devlet teşebbüsü şeklinde kurulmasına karar verilen fabrikaların projelerinin hazırlanması ve İktisat Vekâleti tarafindan onaylanan projelerin gerçekleştirilmesi görevleri yüklenmiştir (TBMM Zabit Ceridesi, 1932a).

Devlet Sanayi Ofisi, Sanayi ve Maadin Bankası'na göre yeni bir sanayileşme modelini temsil etmektedir. Ofis'in Sanayi ve Maadin Bankası'ndan farklı olarak yatırım projeleri hazırlaması ve bu projeleri gerçekleştirmesi yani bir yatırımcı olarak faaliyet göstermesi beklenmiştir.

22.03.1932 tarihinde yapılan Meclis oturumunda, Sanayi ve Maadin Bankası'nın kuruluş amaçlarından biri olan kredi verme faaliyetlerinde de yeterlik gösteremediği vurgulanmıştır (TBMM Zabıt Ceridesi, 1932b). 7 Temmuz 1932 tarihinde kabul edilen 2064 sayılı kanunla Sanayi ve Maadin Bankası'nın kredi faaliyetlerini yürütmek üzere Türkiye Sanayi ve Kredi Bankası kurulmuștur. Banka her türlü bankacılık faaliyetini yürütmek dişında; sanayi işletmelerine ve makine ile sanayi inşaatı malzemelerine kredi açmak, milli sanayi için gerekli hammaddelerin tedarikini sağlamak, Teşvik-i Sanayi Kanunu kapsamında dağıtılacak olan primlerde aracı olmak, sanayi kuruluşlarının ihtiyaç duyacağ 1 gayri-nakit kredileri vermek, küçük kredi kuruluşlarına yardımcı olmak gibi görevleri de üstlenmiştir (TBMM Zabit Ceridesi, 1932b).

Sanayi ve Maadin Bankası'na göre daha katı bir devletçilik anlayışını temsil eden Devlet Sanayi Ofisi ile Sanayi ve Kredi Bankası devletçilikte yeni bir modeli ve dönemi temsil etmektedir. Ancak yeni modelin benimsenmesi hem siyasi hem de özel sermaye çevrelerince devletçilik tartışmalarına son noktayı koyamamış, aksine tartışmaları hızlandırmıştır. Yapılan tartışmalar yeni modelin de kısa ömürlü olmasına yol açmış; sınai gelişimde daha etkin olabilecek tek bir kurumun oluşturulması gündeme gelmiştir. Sümerbank bu kaygıyla 11 Temmuz 1933 tarihinde kurulmuştur. Sümerbank hem devletçiliğin uygulanmasına olanak tanıyan hem de özel sermayenin endişelerini gidermeye çalışan bir yapıyı içermektedir. Dolayısıyla kurumun oluşumundan 'tarihi bir uzlaşma' olarak bahsedilebilir (Tuna, 2009: 59).

Sümerbank, 4 Haziran 1933 tarihinde kabul edilen 2262 sayılı kuruluş kanununda belirtilen görevlerine bakıldığında; Devlet Sanayi Ofisi'nden devralacağı fabrikaları işletmek; özel kanunla kurulacaklar dışında Devlet sermayesi ile teşkil edilecek olan fabrikaları kurmak ve yönetimini üstlenmek; sanayi faaliyetlerine katılmak, sanayi elemanları yetiştirmek için okullar açmak ve yurtdışına öğrenci göndermek; sanayi kuruluşlarına kredi vermek; her türlü banka faaliyetini yürütmek ve ulusal sanayinin gelişimi için faaliyetlerde bulunmakla görevlendirilmiştir (TBMM Zabit Ceridesi, 1932d).

Sümerbank'a ait ilk büyük sanayi işletmesi olan Kayseri Bez Fabrikası ve Lojmanları Eylül 1935' te kurulmuştur. Sümerbank, Türkiye'de ilk modern tekstil kuruluşu olmuştur. Sümerbank bünyesinde demir-çelik tesisleri, çimento fabrikaları, kâğıt ve selüloz tesisleri kurulmuştur. Bu işletmelerin sonradan Sümerbank bünyesinden ayrılarak ayrı birer kuruluş olması sağlanmıştır.
Kurumun özel sermaye ile devlet arasında sağladığı uzlaşmanın ekonomiye etkinlik kazandırdığı düşünülmüş; aynı model farklı sınai alanlarda da devam ettirilerek bu etkinliğin artırılması umut edilmiştir. $\mathrm{Bu}$ amaç doğrultusunda, ekonominin ağır sanayi ayağını temsil etmesi üzere Etibank 14.06.1935 tarihinde 2805 sayılı kanunun kabul edilmesiyle kurulmuştur (TBMM Zabit Ceridesi, 1935a).

TBMM'ne gönderilen tasarıda; Etibank'ın madencilik sektöründe finans işlevi göreceği ve elektrik enerjisi üretimine destek olacağı öngörülmüştür. Kanun metnini gözden geçiren maliye encümenine göre bu işletme birçok milli servetten yararlanılmasını sağlayacaktır (TBMM Zabıt Ceridesi, 1935b). Başvekâlet Umumi Murakabe Heyeti (BUMH) tarafından hazırlanan 1939 yılına ait raporda Etibank'ın kuruluş amaçlarından birinin “ekonomik bağımsızlık” olduğu vurgusu da yapılmıştır (BUMH, 1940: 1).

1937'de bir KİT olarak örgütlenen Denizbank; deniz yolları işletmelerini yönetmek, yenilerini kurmak ve finanse etmek amaciyla kurulmuştur. 1938 yılında kuruluşu tamamlanan banka dönemin önemli kurumlarından olmasına rağmen 1940 yılında çalışmalarına son verilmiştir.

Dönemde KİT niteliğindeki kuruluşların sayıca artması ve faaliyet alanlarının genişletilmesi yasal bir düzenleme gereğini ortaya çıkarmıştır. KİT'lerle ilgili ilk genel tanım, 1938 yllında 17.06.1938 tarih ve 3460 sayılı, "Sermayesinin Tamamı Devlet Tarafindan Verilmek Suretiyle Kurulan İktisadi Teşekküllerin Teşkilatıyla İdare ve Murakabeleri Hakkındaki Kanun" ile yapılmıştır. Buna göre, sermayesinin tamamı devlete ait bulunan ve kuruluş kanunlarında 3460 sayılı kanuna tabi oldukları belirtilen kuruluşların "İktisadi Devlet Teşekkülü” olduğu belirtilmiştir (TBMM Zabıt Ceridesi, 1938).

1964 yılına kadar yürürlükte kalan yasanın temel özelliği kamu iktisadi teşebbüslerinde çeşitliliğe son vererek, benzer bir üretim ve yönetim mekanizmasını kurabilmektir. Bu nedenle kamu iktisadi teşebbüsleri için ortak denetim organları oluşturulmuştur. Umumi heyet ve umumi murakabe heyeti kamu iktisadi teşebbüslerini idari ve mali yönden denetleyecek, kamu iktisadi teşebbüslerinin karar organı idare meclisi olacak, alınan kararlar ise umum müdürlük teşkilatı aracılığı ile yürütülecektir (Aksoy, 1994: 18).

Önceki dönemde çıkarılan ve bu dönem içerisinde yürürlükte olan Sanayi Teşvik Yasasından hem kamu kesimi hem de özel kesim herhangi bir ayrım olmadan yararlanmıştır. Bir önceki dönemin sonu itibariyle teşvik yasasından yararlanan işletmelerin sayısı 1473 iken, 1939'da 1144'e, yasanın son uygulama y1lı olan 1941'de 1052'ye düşmüştür. Teşvikten kamu işletmesinden daha çok özel kesimde faaliyet gösteren işletmeler yararlanmıştır (Kepenek, 1983: 1768).

İlgili dönemde Devletçilik uygulamasının başladığının somut göstergelerinden biri de, 1930'ların başında Birinci Beş Yıllık Sanayileşme Planının kabulü ve uygulanması olmuştur. 1934-1938 yıllarını içeren plan, Türkiye'deki plancılık çabalarının ilk adımlarını oluşturmaktadır. Plan devlet müdahaleciliğinin önemli bir niteliğini de ortaya koymaktadır. Devlet otoritesi, müdahalenin merkezine sanayileşme hedefini oturtmaktadır. 
Uygulamaya konulan Birinci Beş Yıllık Sanayi Planının temel yönelimi, ülke dışından ithal edilen tüketim mallarının, yurt içinde üretiminin sağlanması olmuştur. Özellikle maden işletimi, tekstil, kâğıt, kimya ile çimento sektörlerine ağırlık verilerek tasarlanan planın, bu bakımdan bir yatırım programı niteliği taşıdığı söylenebilir (İnan, 1973: 9-10). Plan ile başarılı sonuçlar alınması üzerine, ikinci beş yıllık sanayi planının hazırlanmasına karar verilmiştir. İkinci beş y1llı plan özellikle ara ve yatırım malı üretiminin artışına yönelik hazırlanmıştır. Beş yıllık süre zarfında gerçekleştirilmek istenen sanayi projelerinden oluşmaktadır. En önemli amaçlarından biri ise, sanayiye konu olan ve ithal edilen temel ürünlerin yurtiçinde üretiminin sağlanmasıdır.

Planın sunuş yazısında, "plana özel girişimciler tarafından kurulması mümkün olmayan tesislerin dâhil edileceği, bunun da özel girişimciler için daha geniş ve yararlı endüstri imkânlarını yaratacağı" ifade edilmiştir. Bu ifade iktisadi kalkınmada Hükümet'in özel girişimciyi tamamen dışlamadığını, devletçi sanayileşmenin, zorunlu ve geçici olduğunu göstermektedir. Devlet bir takım sınai teşebbüsleri özel sektöre ara ve yatırım malı sağlamak için kuracak, üretilen malları özel sektöre ucuz fiyattan satarak bir çeşit sermaye transferi yapmış olacaktır. Planın ana belgesinde, devletçilik uygulamasının özel girişimcilere destek olacağı belirgin biçimde belirtilmektedir (İnan, 1973: 23).

Birinci Beş Yıllık Sanayi Planı, Türkiye'de sanayileşme hedefi bakımından atılan ilk bilinçli adımların göstergesi niteliğindedir. Sahip olunan sınırlı olanaklara ve içerisinde bulunan uygunsuz koşullara rağmen olumlu bir takım olumlu sonuçlar doğurabilmiştir. Planda en büyük ağırlık imalat sanayinin bir alt dalı olarak dokuma sanayine verilmiştir. Programda öngörülen tesisler belirlenen süreler dâhilinde kurulmuş ve başarılı faaliyetlerde bulunmuşlardır. Bu durum karşısında planın bitiş süresi beklenilmeden, 1934-1938 sürecini kapsayacak şekilde İkinci Beş Yıllık Sanayi Planı hazırlanmaya başlanılmıştır. Birinci Beş Yıllık Sanayi Planı'ndan daha detaylı bir içerik ile hazırlanan bu plan içerisinde; madencilik, elektrik santralleri, yakacak sanayi ve ticareti, Toprak sanayi, gıda maddeleri sanayi ve ticareti, kimya, makine ve denizcilik sanayi alanlarında kurulması gereken tesisler, yapılacak yatırım meblağları belirtilmiştir. Özel girişim ve sermaye için plan dışında kalan alanlar önerilmiştir. Ayrıca planda sanayi sektörünün ihtiyaç duyacağı ithalatı karşılayabilmek için ithal ikamesinden çok ihracatı artırmaya ağırlık verilmiştir (Tekeli ve İlkin, 1984: 1603-1604).

Birinci Plana göre daha büyük bir program olan İkinci Planda, 112 milyon TL yatırım yapılması ve 35.000 kişilik istihdam yaratılması öngörülmüştür. Finansman sağlanamadığından hemen uygulamaya konulamamış, öncelikle 1937 yılında planın madencilik ile ilgili yatırımlarını gerçekleştirmek üzere Bakanlar Kurulu kararı ile "Üç Yıllık Maden Programı" adıyla uygulamaya konulmuştur. 1938 yılında İngiliz ve Alman dış yardımının sağlanması üzerinde İkinci Sanayi Planı'nda değişiklikler yapılmış, Üçüncü Sanayi Planı hazırlanmıştır (Tekeli ve İlkin, 1984: 1604). Ancak plan İkinci Dünya Savaşı'nın başlaması ve kaynakların savunma ihtiyaçlarına ayrılması zorunluluğu nedeniyle uygulama olanağını yitirmiştir. Böylece 1933 itibariyle başlayan sanayileşme ve kalkınma çabaları da duraklama devresine girmiştir.
Türkiye Birinci Beș Yıllık Sanayi Planı’nın uygulanması ile birlikte kapitalist sistemin temel niteliklerini muhafaza ederek kalkınma planı uygulayan ilk ülke olmuştur (Talas, 1969: 368). Ancak hem bu plan hem de uygulama imkânı bulunamayan İkinci Beş Yıllık Sanayi Planı, 1963 yılı ile birlikte uygulanmaya başlayan beş yıllık kalkınma planlarından oldukça farklı özellikler taşımaktadır. Beş yıllık sanayi planlarının uygulamaya konma nedeni, dönemin belirli meselelerini çözmek amacı taşımıştır. Bu planlar sadece devletin sanayi ve madencilik alanlarında girişeceği iktisadi faaliyetlerin listesini gösteren birer belge özelliği taşımıştır. Makroekonomik bir bakış açısı ile tasarlanmadıklarından, iktisadi kalkınma planı olmaktan uzak kalmışlardır (Serin, 1963: 119).

İkinci Dünya Savaşının yol açtığı iktisadi etkileri gidermek üzere, iktisat politikaları mal kıtlıklarını ve fiyat artışlarını önleyerek sosyal adaletsizlikleri düzeltme ekseninde şekillenmiştir. Bu doğrultuda 1940 yılında çıkarılan Milli Korunma Kanunu ile mal kıtlıklarının yol açtığı sorunları azaltmak ve spekülatif kazançları önlemek amaçlanmıştır. Milli Korunma Kanunu ile Hükümete geniş bir müdahale alanı verilmiştir. Sanayi kuruluşlarının ve çiftçilerin hangi ürünleri, ne miktarda üretecekleri gibi konularda yaptığı düzenlemelerle devlet, ekonomik yaşama aktif bir biçimde müdahale etmiştir (Hazine Müsteşarlığı, 2003: 12).

Saraçoğlu Hükümeti savaş nedeni ile ortaya çıkan iktisadi zorluklara çözüm yolları aramak için 1944 yılında Harp Sonrası Kalkınma Plan ve Programı'nın hazırlanmasına karar vermiştir. Sümerbank ve Etibank uzmanlarının katkıları ile hazırlanan bu programda, tekstil, kâğıt, inşaat, kimya, makine, madeni eşya, madencilik ve elektrik santralleri yer almış, 1345 milyon TL dolaylarında yatırım yapılması öngörülmüştür. $\mathrm{Bu}$ yatırımların yapılmasından hemen sonra, Sümerbank ve Etibank'a ait yatırım programları tasarlanmış, bu yeni yatırımlar ise 'Beş Yıllık İvedili Sanayi Planı' olarak adlandırılmıştır (Tekeli ve İlkin, 1979-1980: 289).

Beş Y1llık İvedili Sanayi Planı ile sanayileşme hamlesine kalındığı yerden devam edilmek istenmiştir. Sanayileşerek kalkınma ve ulusal bağımsızlık ivedili planın temel hedefi olarak gösterilmiştir (Dav'er, 1946: 2). Özel kesimin kâr maksimizasyonu amacı dişında kalan konulara ve sanayileşme sürecinde ortaya çıkabilecek toplumsal sorunlara duyarsız kalacağı düşünülerek, planın uygulanması konusunda ağırlık devlete verilmiştir (Sezen, 1999: 160).

Sanayi kesimi için 1946 yllında demiryolu ve karayolu yatırımını hedefleyen programlar kabul edilmiş, aynı zamanda yedi yıl süreli, "Büyük Su İşleri Programı" hazırlanmıştır (Tekeli ve İlkin, 1979-1980: 291). Bu dönemde devletçiliğin örgütlenmesi ve kurumsallaşmasını pekiştiren diğer kamu iktisadi teşebbüsleri arasında; Devlet Ziraat İşletmesi ve Toprak Mahsulleri Ofisi, Türkiye Emlak Kredi Bankası ile Makine ve Kimya Endüstrisi Kurumu görülmektedir.

Devlet İvedili Sanayi Planı içerisindeki sanayi projeleri ile Avrupa Kalkınma Programı'na dış yardım talebinde bulunmuştur. $\mathrm{Bu}$ amaçla inceleme yapmak için ABD'den gelen uzmanlar; İvedili Sanayi Planını "devlet sosyalizmi" olarak nitelendirerek uygun bulmadıklarını ifade etmişlerdir. Bu plan yerine hükümetçe, süratle 1947 yılında Vaner planı 
olarak da adlandırılan İktisadi Kalkınma Planı hazırlatılmıştır.

Dönemde devlet müdahaleciliğine bakış açısını gösteren önemli bir gelişme de 1947 yılında yapılan CHP Kurultayı'dır. Kurultay dönemde devletçilik politikalarının yorum ve uygulamaları ile ilgili önemli tartışmalara sahne olmuştur. Uygulamalar neticesinde partinin öz eleştirisinin yapıldığı kurultayda, yeni bir program belirlenmiş; bu programla zaten önceden de var olan müdahaleciliğin sınırlarının ne olması gerektiği ve özel teşebbüsün gelişim süreçlerine ilişkin dinamiklere vurgu yapılmıştır (Cumhuriyet Halk Partisi, 1948: 89-93).

Devletin ekonomik yaşama yalnızca düzenleyici olarak değil, fakat aynı zamanda doğrudan girişimci olarak katıldığı 1933-1950 döneminde, ekonomi siyasası sanayileşme üzerine temellendirilmiştir. Dönem boyunca uygulanan devletçilik modeli hiçbir zaman bir sistem olarak tasarlanmamış, herhangi bir ideolojinin ürünü olmamıştır. Model tam anlamıyla ülkenin iktisadi koşullarına bağlı olarak dönemin gerçeklerinden hareketle tasarlanmış ve uygulanmıştır. Model içerisinde özel girişim ekonomi içerisinde varlığını ve gelişmesini sürdürmüştür. 1933-1950 döneminde devletçilik Anayasa'ya da girmesine karşılık, uygulanan iktisat politikası geniş ölçüde kapitalist esaslara dayanmıştır.

\section{Devlet Müdahaleciliğinin Kurumsallaşmasında Önemli Bir Yapıtaşı: Etibank}

Türkiye'de sınai alanda devletin kendi teşebbüs ve sermayesi ile fabrika kurması ve işletmesi, 19. yüzyılın ikinci yarısına doğru başlamıştır. Bu alandaki devlet işletmeciliği başlıca 3 farklı aşamayı içermiştir. Birinci aşamada devlet işletmeleri daha çok resmi ve askeri ihtiyaçları karşılamak amacıyla kurulmuş, doğrudan ilgili Devlet dairelerine bağlı olarak faaliyette bulunmuşlardır. Cumhuriyet ile başlayan ikinci aşamada, resmi kurumlar Sanayi ve Maadin Bankası'na devredilerek, devlet işletmelerine iktisadi ve ticari bir nitelik kazandırılmak istenmiş; sanayi planlarının hazırlanması ve Sümerbank'ın kurulmasıyla başlayan üçüncü aşamada ise geniş ölçüde ve planlı bir devlet işletmeciliği rejimine girilmiştir (Apak, 1952: 263).

Birinci Beş Yıllık Sanayi Planı'nın içeriğine bakıldığında, Sümerbank ve Türkiye İş Bankası'nın yapacağı faaliyetleri üzerinde durmakta, madencilik alanı üzerinde çok fazla durmamaktadır. Sanayi Planı ile maden sahasında devletin işletmeci olarak faaliyet göstermesi planlanmamış, ancak bu alanda devlet organizasyonunun gerekliliği vurgulanmıştır. Ayrıca madencilik sektörünün öneminden dolayı bir jeoloji enstitüsünün kurulmasına karar verilmiştir. Maden işletmeciliği faaliyetleri ile enerji üretim ve dağıtım süreçleri, devlet müdahaleciliğinin daha sistematik bir şekilde ele alınmasını gerektirmiştir (Toros, 1954: 178). Maden ve enerji alanında devletin işletmeci sıfatıyla faaliyette bulunması, 1935 yılında Etibank'ın kurulmasıyla kararlaştırılmıştır. Etibank ile birlikte Etibank'ın faaliyetlerinin verimini artırmak amaciyla; Maden Tetkik Arama Enstitüsü ve Elektrik İşleri Etüd İdaresi'nin de kurulmasına karar verilmiştir.

Maden Tetkik ve Araştırma Enstitüsü'nün kurulmasına, 1935 yılında TBMM'ne sunulan 2804 sayılı kanun ile karar verilmiştir. Kanuna göre; maden kaynaklarının tetkik edilmesi ve aranması görevi Enstitü tarafindan üstlenilecek; bu vesileyle maden aramaya ilişkin tüm riskler Hükümet tarafından üstlenilmiş olacaktır. 1936 yılında hazırlanan İkinci Beş Yıllık Sanayi Planı, Etibank tarafından, Şark Kromlar, Ferro Krom Sanayi, Ergani Bakır Madeni, Kuvarshan ve Murgul Bakır Madenleri, krom ve bakır dışındaki metal madenler, Ereğli Kömür Havzası, Kütahya Linyit Havzası, Mıntıka Elektrik Santralleri yatırımlarının yapılmasını tasarlamıştır (Toros, 1954: 180).

Etibank 1935 yılında kurulmuş, yaklaşık beş ay süren bir hazırlık sürecinin tamamlanması sonrasında faaliyetlerine başlamıştır. Etibank 1936 yılından itibaren kuruluş kanunun tahmil ettiği maden ve elektrik enerjisi üretimine başlamış ve faaliyet sahasını yıldan yıla geliştirmiştir. Kuruluşunu takip eden ilk yıllarda maden yatırımlarında bulunan Banka'nın, enerji sektöründe faaliyette bulunabilmesi, İkinci Dünya Savaşı'nın sona ermesiyle mümkün olmuştur. Banka kuruluşunu izleyen ilk yıllarda; kömür, linyit, krom, demir ve bakır madenlerine yönelik yatırımlarda bulunmuş, ayrıca enerji alanında bir elektrik santrali yapımını üstlenmiştir. $\mathrm{Bu}$ süre zarfında kuruluş kanununda belirtildiği şekilde; bazı maden kuruluşlarını devralmış, bazı işletmeleri ise bizzat kurma görevini üstlenmiştir.

Etibank'ın 2805 sayılı kuruluş kanununda belirtilen görevleri arasında; maden cevherleri, taşocağı maddeleri, madeni hammadde ve maden malzemesi alım satımı yapmak; petrol ve maden arama ruhsatnameleri vermek; maden imtiyazı, ruhsatnamesi ve hisselerini çıkarmak; elektrik enerjisi üretmek ve dağıtımını yapmak, elektrik santrali kurmak, elektrik malzemesi üreten fabrikalar kurmak; elektrik malzemesi ve makineleri alım satımı yapmak; tüm bu alanlarda faaliyet gösterecek teşebbüsler kurmak ya da yurtiçi ve yurtdışında bu amaçla teşkil olunan kurumlara ortaklık etmek ve son olarak her türlü bankacılık faaliyetlerini gerçekleştirmek bulunmaktadır (TBMM Zabıt Ceridesi, 1935a).

Etibank, bir taraftan faaliyet sahası olan sanayi sektörünün arz ettiği tabiî zorlukları teknik yenilikleri tahakkuk ettirmek suretiyle yenmeye, bu sahayı memleket menfaatlerine en uygun bir şekilde geliştirmeye çalışırken, diğer taraftan da önceki yıllarda hem yeraltı zenginliklerini, hem de emek gücünü istismar etmiş olan yabancı şirketlerin tâbi bulunmadıkları ya da uygulamaktan kaçındıkları kanuni yükümlülükleri uygulamaya mecbur bulunuyordu. Bu çift cepheli yükümlülüklere; mahsulünü, halkın temel ihtiyaçlarından olması nedeniyle maliyet ve kâr esaslarına göre belirleyen bir fiyata değil ancak halka makul gelecek bir fiyata satma yükümlülüğü de eklenmiştir. Aynı zamanda hem sanayii modernleştirme, hem sosyal adaletin gerektirdiği şartlara göre işçinin hakkını verme, hem de her ikisi de maliyeti yükseltici gayretler olmasına rağmen, ürettiği mahsulü ancak "belirli" bir fiyata satabilen Etibank'ın bu birbiriyle çelişen problemleri eş zamanlı olarak çözüme kavuşturması kolay olmamıştır (Topçuoğlu, 1956: 288-289).

Etibank, yepyeni bir sınaî tesisi dilediği gibi yaratıp işletecek durumda olmayıp, birçok kusuru barındıran bir geçmiş bakiyesini devralmış bir kurum olarak görünmektedir. Alman iktisatçı ve toplumbilimci Ord. Prof. Dr. Gernard Kessler, Zonguldak ve Karabük'teki çalışma şartları üzerine 
yaptığı çalışmada, Etibank'ın içerisinde bulunduğu durumu şöyle betimlemiştir: " Devlet, yaklaşık on sene evvel bütün kömür Havzasının işletmesini üzerine aldığı zaman karşısında en bedbaht çalışma şartlarını buldu; burası hakikî maden ișçisi olmayan bir maden havzası idi ve ücretleri düşük, kötü bakılan kötü yerlerde barındırılan ve tamamıyla bilgisiz olarak ocaklarda çalıştırılan bu zavallı gündelikçi köylülerden faza bir şey, yâni kötü ve verimsiz işten başka bir şey beklenemezdi" (Kessler,1949: 13).

Devleti ağır sanayi alanında temsil etmek üzere ülkede maden ve enerji üretimini gerçekleştirmek gibi büyük bir sorumluluğu üstlenen Etibank; üretim sürecinde sermaye, alt yapı ve işgücü yetersizliği gibi pek çok sorunla karşılaşmıştır. Üretim yapılan tesislerde verimliliği ve üretimi artırmak için pek çok yatırım programı hazırlamış, bu yatırım programları dâhilinde tesislerin bakım ve onarım faaliyetlerini gerçekleştirmiştir (BUMH, 1942: 3-5). Kurum aynı zamanda kuruluş esasına uygun olarak piyasaya üretim maliyetlerinin altında hammadde sağlamaya çalışmıştır (BUMH, 1948: 13-14; BUMH, 1949: 21).

Sektörün niteliğinden dolayı karşılaşılan önemli bir sorunda işgücü bulma sıkıntısı olmuştur. Bu durum Murakabe Heyeti Raporlarında sıklıkla dile getirilmiş, uluslararası alanda da bu sorunla karşılaşan ülkelerden bahsedilmiştir (BUMH, 1941: 4). Bu sorunu aşabilmek için Etibank yönetimi personele giyim ve yiyecek başta olmak üzere karşılıksız yardımlarda bulunmuş, barınma ihtiyacını gidermek üzere lojman tahsis etmiştir. İşgücü sorunları çözmek için çok tartışmaya yol açan İş Mükellefiyeti Kanunu'nu yürürlüğe koymuştur (BUMH, 1944: 91).

Etibank'ın işgücü politikalarına dönük olarak dikkat çeken başka bir husus, ihtisaslaşmış personel eksikliği sorununu gidermek üzere uygulanan yabancı eleman istihdamıdır. Kurum işinde uzman yabancı eleman istihdamına izin vererek, hem ihtisaslaşmış personel eksikliğini gidermeye çalışmış, hem de kurumda çalışan diğer personelin uzmanlaşmış kişilerce eğitimini amaçlamıştır.

Etibank Türkiye'de devlet müdahaleciliğinin kurumsallaşması sürecinde en önemli yapı taşlarından biridir. Etibank, Türkiye'de görülen müdahalecilik anlayışına uygun olarak; kaynak kullanımındaki etkinliğin sağlanması için devleti ağır sanayi alanında temsil etmek üzere kurulmuştur. $\mathrm{Bu}$ süreçte yerli kaynakların kullanımında iktisaden bağımsız olmak ve devlet-özel sermaye arasındaki işbirliğini sağlamak en önemli hedefleri olmuştur. Etibank bünyesinde faaliyet gösteren müesseseler, bankanın kuruluş kanununda belirtildiği şekilde zaman içerisinde özel sermayeye devredilmiştir.

\section{Sonuç}

İktisat literatüründe müdahaleciliğin temel gerekçelerinin ortaya konulması devlet müdahaleciliğinin meşruiyetinin artmasını sağlamıştır. Tarihsel nedenlerle kapitalist gelişme sürecine geç giren Türkiye ve benzeri ülkelerde, 1929 krizi ile birlikte teorik anlamda gerekliliği anlaşılan müdahaleci süreç, İkinci Dünya Savaşı sonrası devam eden süreçte geniş bir uygulama alanı bulmuştur. Türkiye'de uygulanan müdahalecilik modeli bu açıdan diğer gelişmekte olan ülkelerle benzerlik taşımakla birlikte önemli bir ayırıcı niteliği de içermektedir.
Türkiye'de devletçilik ile serbest piyasa ekseninde uygulanan iktisat politikası seçenekleri, devletin iktisadi bir aktör olarak ön planda olduğunu gözler önüne sermektedir. Devlet Cumhuriyetin kuruluş yılları itibariyle kapitalist gelișim sürecinin en temel öğesi haline gelmiștir. Üstlendiği bu konumu özel kesimin gelişimi için kullanmış olması öznel bir unsuru olarak göze çarpmaktadır. Farklı bir ifade ile Türkiye'de devlet müdahaleciliğinin, özel kesimi güçlendirecek şekilde kurumsal bir model olarak yapılandırılması amaçlanmıştır.

Etibank kuruluş kanununda yer alan bilgiler ve kurumun 1950 y1lına kadar süregelen faaliyetleri incelendiğinde; kuruluş kanununa paralel biçimde ağır sanayinin özel kesim tarafindan yürütülmesi gerektiğine olan inanç gözlenmektedir. Müdahalecilik ekseninde uygulanan kurumsal düzenlemeler, amaçlanan temel hedefin özel kesimi güçlendirmek olduğunu gözler önüne sermektedir. $\mathrm{Bu}$ bağlamda Türkiye'de devlet müdahaleciliğinin pragmatik nitelikler sergilediği söylenilebilir.

\section{Kaynakça}

Ahmad, F. (1980). Vanguard of a Nascent Bourgeoisie: The Social and Economic Policy of the Young Turks 19081918. Türkiye'nin Sosyal ve Ekonomik Tarihi 1071-1920. Ankara: Meteksan Limited Şirketi.

Aksoy, Ş. (1994). Türkiye'de Kamu İktisadi Teşebbüsleri: Genel Bir Bakış. Amme İdaresi Dergisi, 27(2), 1-21.

Âli İktisat Meclisi (1933). Türkiye'de Sanayi Nasıl Teessüs ve İnkişaf Edebilir?. Ankara: Başvekâlet Müdevvenat Matbaasi.

Alp, T. (1936). Kemalizm. İstanbul: Cumhuriyet Gazetesi Matbaası.

Altıntaş, M. (1978). Türkiye'de Planlı Kalkınma ve Uygulama Sonuçları. Ankara: İktisadi ve Ticari İlimler Akademisi Muğla İşletmecilik Yüksek Okulu Yayını.

Apak, K. (1952). Türkiye'de Devlet Sanayi ve Maadin Işletmeleri. İzmit: Selüloz Basımevi.

Aysan, M. (1980). 100. Doğum Yıldönümünde Atatürk'ün Ekonomi Politikasl. İstanbul: İstanbul Üniversitesi Yayınları.

BUMH (1940). Etibank 1939 Yll Umumi Murakabe Heyeti Raporu. Ankara: Başbakanlık Umumi Murakabe Heyeti.

BUMH (1941). Etibank 1940 Yılı Umumi Murakabe Heyeti Raporu. Ankara: Başbakanlık Umumi Murakabe Heyeti.

BUMH (1942). Etibank 1941 Yılı Umumi Murakabe Heyeti Raporu. Ankara: Başbakanlık Umumi Murakabe Heyeti.

BUMH (1944). Etibank 1943 Yll Umumi Murakabe Heyeti Raporu. Ankara: Başbakanlık Umumi Murakabe Heyeti.

BUMH (1948). Etibank 1947 Yll Umumi Murakabe Heyeti Raporu. Ankara: Başbakanlık Umumi Murakabe Heyeti.

BUMH (1949). Etibank 1948 Yll Umumi Murakabe Heyeti Raporu. Ankara: Başbakanlık Umumi Murakabe Heyeti.

Boratav, K. (1974). 100 Soruda Türkiye'de Devletçilik. İstanbul: GerçekYayınları. 
Cumhuriyet Halk Partisi (1948). Yedinci Kurultay Tutanăğ. Ankara: Ulus Basımevi.

Çavdar, T. (1983). Cumhuriyet Döneminde Türk İktisat Düşüncesi. Cumhuriyet Dönemi Türkiye Ansiklopedisi. İstanbul: İletişim Yayınları.

Çavdar, T. (2003). Türkiye Ekonomisinin Tarihi. Ankara: İmge Kitabevi.

Dav'er, A. (1946, 18 May1s). Yeni Sanayi Hamlemize Dair. Cumhuriyet Gazetesi.

Derin, H. (1940). Türkiye'de Devletçilik. İstanbul: Çituri Biraderler Basımevi.

Gevgilili, A. (1987). Yükseliş ve Düşüş. İstanbul: Bağlam Yayınevi.

Hazine Müsteşarlığı (2003). 1923-2003 Türkiye Ekonomisi. Cumhuriyetin 80.Yılı Özel Sayısı. Ankara.

Herslag, Z. Y. (1995). Atatürk'ün Devletçiliği. İçinde: Nevin Coşar (Ed.), Türkiye'de Devletçilik. İstanbul: Bağlam Yayınları.

İnan A. (1973). Devletçilik Illkesi ve Türkiye Cumhuriyetinin Birinci Sanayi Planı. Ankara: Türk Tarih Kurumu.

İnönü, İ. (1933). Firkamızın Devletçilik Vasfi. Kadro Aylık Fikir Mecmuası, 2(22), 2-18.

Kazgan, G. (1978). Türk Ekonomisinde 1927-1935 Depresyonu, Kapital Birikimi ve Örgütleşmeler. Atatürk Döneminin Ekonomik ve Toplumsal Tarihiyle Ilgili Sorunlar Sempozyumu. İstanbul: İstanbul Yüksek İktisat ve Ticaret Mektebi Mezunları Derneği Yayınları.

Kepenek, Y. (1983). Türkiye'nin Sanayileşme Sorunları. Cumhuriyet Dönemi Türkiye Ansiklopedisi. İstanbul: İletişim Yayınları.

Kessler, G. (1949). Zonguldak ve Karabükteki Çalışma Şartları. İçtimâ̂ Siyaset Konferansları, İstanbul, Kitap: II.

Keyder, Ç. (1993). Ulusal Kalkınmacılı̆̆ın Iflası, İstanbul: Metis Yayınları.

Kuyucuklu, N. (1986). Türkiye İktisadı. İstanbul: Beta Basım Yayım.

Laufenburger, H. (1941). İktisadi Sahada Devletin Müdahalesi. (Çev: Zekai Apaydın). İstanbul: Ahmed İhsan Matbaası.

Okyar, O. (1995). Devletçilik Kavramı. İçinde: Nevin Coşar (Ed.), Türkiye'de Devletçilik. İstanbul: Bağlam Yayınları.

Pamuk, Ş. (2012). Osmanlıdan Cumhuriyete Küreselleşme, Iktisat Politikaları ve Büyüme. İstanbul: İş Bankası Kültür Yayınları.

Serin, N. (1963). Türkiye ’nin Sanayileşmesi. Ankara: Sevinç Matbaas1.

Sezen, S. (1999). Devletçilikten Özelleştirmeye Türkiye'de Planlama. Ankara: Türkiye ve Orta Doğu Amme İdaresi Enstitüsü Yayını.

Talas, C. (1969). Ekonomik Sistemler. Ankara: Sevinç Matbaas1.
TBMM Zabit Ceridesi (1925). Devre II, Cilt 18, Intikat 105'e ek. Ankara: TBMM Matbaası.

TBMM Zabit Ceridesi (1932a). Devre IV, Cilt 9, İnikat 77’Ye ek, Sira No: 265. Ankara: TBMM Matbaası.

TBMM Zabit Ceridesi (1932b). Devre IV, Cilt 9, İnikat 80’e ek, Sira No:270,Ankara: TBMM Matbaası.

TBMM Zabit Ceridesi (1932c). Devre IV, Cilt 9. Ankara: TBMM Matbaası.

TBMM Zabit Ceridesi (1932d). Devre IV, Cilt 16, 65. İnikad. Ankara: TBMM Matbaası.

TBMM Zabıt Ceridesi (1935a). Devre V, cilt 4, Birleşim: 38. Ankara: TBMM Matbaası.

TBMM Zabit Ceridesi (1938). Devre V, Cilt 26. Ankara: TBMM Matbaası

TBMM Zabit Ceridesi. (1935b). Devre V, Cilt 4, İnikat 18'e ek. Ankara: TBMM Matbaası.

Tekeli, İ., \& İlkin, S. (1977). 1929 Dünya Buhranında Türkiye'nin İktisadi Politika Arayışları. Türkiye Belgesel İktisat Tarihi Serisi. Ankara: ODTÜ Yayınları.

Tekeli, İ., \& İlkin, S. (1979-1980). II. Dünya Savaşı Sırasında Hazırlanan Savaş Sonrası Kalkınma Plan ve Programları. ODTÜ Gelişme Dergisi, Özel Sayı, 289325.

Tekeli, İ., \& İlkin, S. (1984). Türkiye'de Planlama: Ülkesel, Bölgesel, Kentsel. Cumhuriyet Dönemi Türkiye Ansiklopedisi. İstanbul: İletişim Yayınları.

Tezel, Y.S. (2000). Cumhuriyet Döneminin İktisadi Tarihi (1923 - 1950). İstanbul: Tarih Vakfi Yurt Yayınları.

Topçuoğlu, H. (1956). Etibank ve Sosyal Politikası. Ankara Üniversitesi Hukuk Fakültesi Dergisi, 13(1), 287-328.

Toros, H. (1954). Türkiye Sanayi Devlet Işsletmeleri. İstanbul: Güven Basımevi.

Tuna, S. (2009). Türkiye'de Devlet İşletmeciliği ve Sümerbank (1932- 1939). İstanbul: DerlemYayınları. 